\title{
EESTLASTE JA EESTI KEELE PÄRITOLUST: VAHEKOKKUVÕTTEKS ${ }^{1}$
}

\author{
Ago Künnap \\ Tartu Ülikool
}

Kokkuvõte. Geneetikud on tõestanud uurali keelte kõnelejate saabumise Euroopasse idast. Artiklis on esitatud soomlaste ja eestlaste saabumise teed.

Vastavalt rahvusvahelise geneetikute rühma uurimistulemustele (Bramanti jt 2009) kuulus 80 protsendi küttide-korilaste emaliinide DNA-st tüüpi, mis on tänapäeva eurooplaste seas üsna haruldane, esinedes tavaliselt 10 protsendil, põhjaeurooplastel 20 protsendil.

Mõned uralistid on hakanud pidama eesti ja teiste uurali keelte oletatavat algkeelt suhteliselt nooreks. Nad oletavad, et selle algkeele lagunemine algas alles umbes 4000 aasta eest.

Märksõnad: uurali keeled, eesti keel, soome keel, uurali algkeel, populatsioonigeneetika

\section{Sissejuhatus}

Meie austatud juubilar professor Helle Metslang on eriti silmapaistvate tulemustega uurinud eesti keelt mitmest aspektist. Kuid samas pole ikka veel päris selge, kust on pärit see keel, mida tema ja me teised uurime, ja selle keele kõnelejad ise. Praegu on sobiv hetk päritolu-uuringute põgusaks vahekokkuvõtteks. Hetke sobivus johtub asjaolust, et oleme taas päritolu-uuringute kriitlises pöördepunktis. Pöörde on järjekordselt tekitanud populatsioonigeneetika uued andmed. Ainult vahekokkuvõtteks sellepärast, et vastava uurimistöö lõpp-punkt veel ei paista ja pole teada, kas ta kunagi paistma hakkabki. Käsitluse põgusus on tingitud minu kui eelkõige uurali keelte morfosüntaksiga tegeleja paratamatust eemaltvaatajapositsioonist kõneks olevate probleemide suhtes.

1 Käesoleva artikli avaldamist on toetanud Eesti Teadusfondi grant 7724. 
Juba mõne aja eest on geneetiliselt tõestatud eestlaste esiisade ühe osa saabumine Eesti alale Siberist. Eestlaste esivanemate lähtumist Siberist on oletatud juba väga ammu, kuid seda ebamäärase suurema või väiksema inimkogumina. Nüüdseks on aga ilmnenud, et siin peab eritlema teatud geneetilisi inimrühmi, sest need on lähtunud erinevaist paikkondadest ja kulgenud mööda erinevaid marsruute. Inimese pärilikkuse põlvest põlve edasikandumise mehhanism on üldiselt väga püsiv. Kuid vahel juhtub, et selles toimuvad siiski muutused. Neid muutusi eristatakse geneetiliste haplorühmade põhjal. Uusi haplorühmi tuleb niisiis vähehaaval juurde. On võimalik eristada meeste ja naiste haplorühmi. Uuemate populatsioonigeneetika andmete põhjal on Kalevi Wiik mõne aasta eest joonistanud kaardid soomlaste peamiste haplorühmade skemaatiliste saabumismarsruutidega kõigi inimeste ühisest algkodust Aafrikast Soome (vt joonised 1 ja 2). Haplorühmi tähistatakse suurtähtedega (nt N). Wiik kasutab lisaks veel haplorühmade tähistest lähtuvaid leppelisi eesnimesid (nt joonisel $1 \mathrm{~N}>$ Niilo). Mustade joonte paksus joonistel tähistab seda, kui suur protsent soomlaste esivanematest on mingit marsruuti Soome saabumisel kasutanud. Või õigemini: kui suur protsent Soome meestest ja naistest on mingit marsruuti mööda Soome saabunu(te) geneetilised järglased, sest saabujate absoluutarvu ja eri marsruute mööda saabujate arvulist vahekorda me ju ei tea (ühe haplorühma esindajate mingi hulga tekkimiseks põhimõtteliselt piisanuks, kui Soome saabunuks üksainuski selle haplorühma esindaja).

Samu jooniseid 1 ja 2 võib mõningate mööndustega kasutada ka eestlaste peamiste haplorühmade Eestisse saabumise skemaatiliseks kujutamiseks. Nimelt peaks selleks joonisel 1 kustutama haplorühma Maria marsruutjoone, sest Eestist pole teada Maria järglasi. Lisaks tuleks arvuliselt täpsustada mõlema joonise marsruutjoonte protsentuaalseid väärtusi, mis oleksid järgmised (kahe eri väärtuse paralleelse esinemise korral on tegemist eri andmeallikatega): joonis 1 (vastava meeste haplorühma liikmete protsent kõikidest Eesti meestest) - Niilo 31-37, Raul 27-36, Robert 8-13, Ivar 15-19, Karl 1-9; joonis 2 (vastava naiste haplorühma liikmete protsent kõigist Eesti naistest) - Velda 3-4, Helena 44-45, Jasmine 10, Tara 7-8, Ursula 26-27, Xenia 1, Iris 
1, Wilma 3 (Wiik 2007b: 105, 108-111, 145, 165-189). Kõige silmatorkavam visuaalne viga eestlaste päritolu seisukohast on nendel joonistel see, et Rauli marsruutjoon ei tohiks olla joonisel 1 palju peenem kui Niilo oma ning mõlema joonise kõik marsruutjooned peaksid lõppema Eestis.

Joonis 1. Soome meeste Soome saabumise marsruudid (Joonis 1 pärineb käsikirjast Wiik 2007a; avaldatud trükis Wiik 2009: 40)

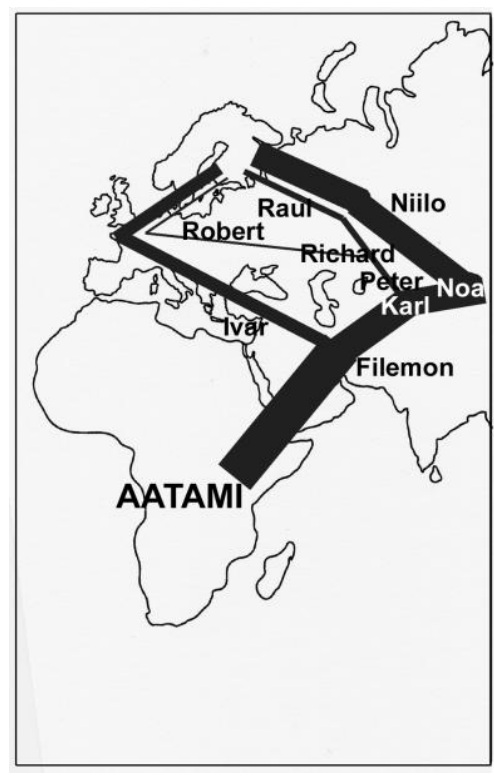

Joonis 2. Soome naiste Soome saabumise marsruudid (Joonis2 pärineb käsikirjast Wiik 2007a; avaldatud trükis Wiik 2009: 40)

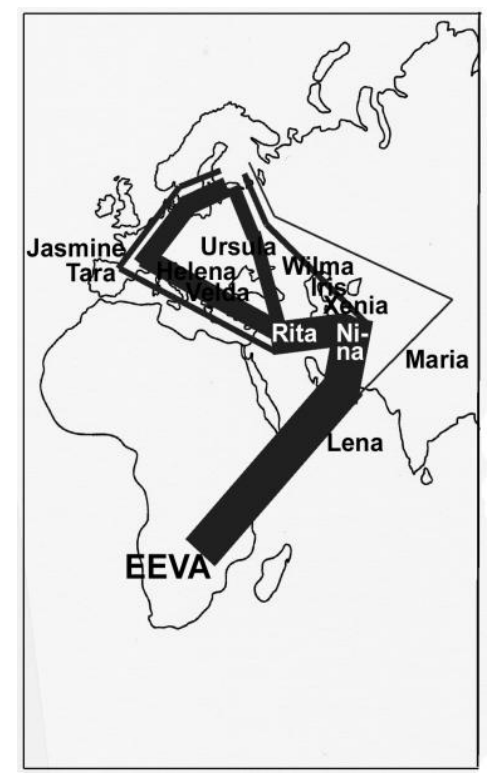

Joonisel 1 on Eesti meeste haplorühmade korral selgesti näha just Niilo tulek läänepoolsest Siberist (Niilo eellasrühm Noa pärineb lõunapoolsest Siberist või koguni Hiinast). Aasiast põlvnevad kaugemas perspektiivis ka haplorühmad Robert ja Raul, samuti viimaste lõunapoolsest Kesk-Aasiast pärineva eellasrühma Karli järeltulijad. Ivargi on Aasia päritoluga - ta põlvneb Lähis-Idast. Joonisel 2 näeme, et kõik Eesti naised on kaugemas perspektiivis Aasia - täpsemini Lähis-Ida (Rita) ja läänepoolse 
Kesk-Aasia (Nina) - päritoluga. (Wiik 2007b: 93-104, 152-159, 162-165, 186-188.) Niisiis on kõik eestlased lõppkokkuvõttes saabunud ida poolt (nagu teisedki eurooplased). Hoopis iseküsimus on see, kustkaudu kulgesid eestlaste esivanemate marsruudid Euroopas enne Eestisse saabumist (mingi umbkaudse ettekujutuse sellest saab küll ka vaatlusalustelt skemaatilistelt kaartidelt). Euroopa ulatuses võime rääkida saabumisest ka teistest põhi- või vaheilmakaartest. Nii et eestlaste ida poolt tuleku jaatamine või eitamine sõltub õigupoolest vaatluse ulatusest: kas kogu Euraasia või ainult Euroopa.

Hetkel on tõsisemalt tõstatunud mõned küsimused Euroopa elanike päritolust. Ligi sajandi on teadlased vaielnud selle üle, kas varajased Euroopa põldurid olid valdavalt sisserändajad või tol ajal Euroopas juba elanud küttide-korilaste järeltulijad, kes põlluharimiskultuuri üle võtsid. Sügisel 2009 tutvustas üks rahvusvaheline teadlasrühm oma uurimistulemusi ajakirjas "Science" (Bramanti jt 2009). Rühm on uurinud arheoloogilisi inimluuleide Kesk-Euroopas (Saksamaal, Austrias, Leedus, Ungaris, Venemaal ja Poolas). 22 küti-korilase 4 000-15 000 aasta vanustest luudest õnnestus saada andmeid geneetiliste emaliinide, s.o naiste DNA kohta. Neid andmeid võrreldi Kesk-Euroopa esimeste, 7 000-7 500 aastat tagasi saabunud põldurite ja tänapäeva elanike emaliinidega. Need kolm rühma osutusid geneetiliselt väga erinevaks. Mitte selles mõttes, et oleks leitud senitundmatuid haplorühmi, vaid juba tuntud haplorühmade tollane levik oli tänapäevasest tunduvalt erinev. Nii kuulus küttide-korilaste DNA üle 80 protsendil juhtudest ühte niisugusesse tüüpi, mida leiab eurooplaste seas suhteliselt harva, tavaliselt kuni 10 protsendi, põhjaeurooplastel paarikümne protsendi ulatuses. Seega vähemalt alguses kütid-korilased ja põldurid omavahel ei segunenud, seejuures seni teadmata põhjustel. Vastavate emaliinide edaspidised arheoloogilised leiud ja sellele lisaks ka isaliinide ehk teisisõnu meeste DNA uurimine võib tuua uusi üllatusi. Kesk-Euroopa põlduritest immigrantide päritolu väljaselgitamiseks peab analüüsima Euroopa kaguosa ja Türgi ala põldurite vana DNA-d. Kõnealusest avastusest ei saa me esialgu teha mingeid otseseid järeldusi eestlaste päritolu kohta, kuid edasiste leidude korral pole see võimalus välistatud. Igatahes leiab veel 
kord kinnitust asjaolu, et eestlastel esinevate eri haplorühmade omavahelised prontsentuaalsed vahekorrad ei tarvitsenud kaugemas minevikus olla samad kui tänapäeval.

Eesti keele ajaloo seisukohast on huvitav, et mitmed uurali keeleteadlased on viimasel ajal pidanud eesti keele ja teiste uurali keelte leppelist kaugemat lähet - uurali algkeelt - suhteliselt nooreks nähtuseks. Nii algas selle algkeele oletatav lagunemine näiteks Petri Kallio ja Jaakko Häkkise hiljuti avaldatud ja muide üsnagi usutavalt põhjendatud oletuste kohaselt alles põhjapoolse pronksiaja alguses umbes 4000 aasta eest (Kallio 2006: 16-17 ja Häkkinen 2009: 30, 45). Seejuures uurali keelte ulatuslikum levik toimus Häkkise arvates kõigest kahe viimase aastatuhande jooksul (Häkkinen 2009: 46). Nii hilise leviku korral pidi Eesti alal, mis on olnud juba 10000 aasta eest mannerjääst vaba ning inimese poolt asustatud, räägitama enne uurali keelekuju saabumist mingit muusugust keelekuju. Nimetatud uued keeleajaloolised oletused jäävad - erinevalt populatsioonigeneetika vaevalt et vaidlustatavast faktoloogiast - siiski vaid oletusteks.

\author{
Ago Künnap \\ Eesti ja üldkeeleteaduse instituut \\ Tartu ülikool \\ Ülikooli 18 \\ 50090 Tartu \\ Ago.Kunnap@ut.ee
}

\title{
Kirjandus
}

Bramanti jt 2009 = Bramanti, B., M. G. Thomas, W. Haak, M. Unterlaender, P. Jores, K. Tambets, I. Antanaitis-Jacobs, M. N. Haidle, R. Jankauskas, C.-J. Kind, F. Lueth, T. Terberger, J. Hiller, S. Matsumura, P. Forster, J. Burger (2009) "Genetic discontinuity between local hunter-gatherers and Central Europe's first farmers". Science 2 October 2009 (vol. 326. no. 5949), 137-140.

Kallio, Petri (2006) "Suomen kantakielten absoluuttista kronologiaa". Virittäjä 110, 1, 2-25. 
Eestlaste ja eesti keele päritolust: vahekokkuvõtteks

Häkkinen, Jaakko (2009) "Kantauralin ajoitus ja paikannus: perustelut puntarissa". Suomalais-Ugrilaisen Seuran Aikakauskirja 92, 9-56.

Wiik, Kalevi (2007a) Genetiikkaa sukututkijoille ja väestöjen juurtenetsijöille. 27.04.2007. (Käsikiri.)

Wiik, Kalevi (2007b) Mistä suomalaiset ovat tulleet. [Tampere]: Pilotkustannus Oy.

Wiik, Kalevi (2009) Genetiikkaa sukututkijoille ja väestöjen juurtenetsijöille. Turku: Uniprint.

Ago Künnap. On the Newest Data about the Origin of Estonian Population and Language. Genetic research has shown that the present Uralic-speaking population arrived in Europe from the east. In the paper the routes of Finns and Estonians are presented.

Recently an international group of scientists introduced their research outcomes (Bramanti jt 2009). The group had investigated archaeological findings of human bones in Central Europe. Within more than $80 \%$ of cases the maternal DNA lineage of hunters-gatherers belonged to such a type which is relatively rare among contemporary Europeans, ordinarily around 10\%, among Northern Europeans around $20 \%$.

Several Uralists have started to regard the presumed more distant common origin of Estonian and other Uralic languages - Proto-Uralic - as a relatively young phenomenon. The supposed disintegration of the named proto-language would have begun only about 4,000 years back.

Keywords: Uralic languages, Estonian, Finnish, Proto-Uralic, population genetics. 